\title{
The Effects of Lead Contamination in Public Health Case: Pesarean Village, Tegal District, Indonesia
}

\author{
Indah Lestari ${ }^{1}$, Tri Edhi Budhi Soesilo ${ }^{1, *}$, and Haruki Agustina ${ }^{1}$ \\ ${ }^{1}$ School of Environmental Science, Universitas Indonesia, Indonesia.
}

\begin{abstract}
Lead is one of the ten main chemicals that was found naturally in the earth's crust and has toxic effects to human health. Direct contamination due to the re-suspension of dust containing lead from soil can be inhaled by certain environmental conditions, for example in dry season and enter human body directly. The aim of this study was analyzing the effect of lead contamination toward human health in Pasarean Village.The research was conducted in Pesarean Village, Tegal District where metal smelting and used lead acid battery smelting had been done in more than 10 years ago and left the waste aside as an open dumping waste. The method that was used in this study were qualitative method using questionnaire and reviewing secondary data which was supported with literature reviews. The result showed that almost $80 \%$ of people has acute and chronic symptoms of lead poisoning and it showed that lead contained in blood was high or exceeding the blood lead level standard in human.
\end{abstract}

\section{Introduction}

Interaction is a major idea in ecology to understand the relationship between biological individuals, communities their relationship [1]. In the environment, there is a relationship from interaction between individuals in a group, living in an area and reflecting the relationship between phenomena in the environment [2]. Soil pollution is a condition where the chemicals enter and alter the natural soil of environment. The interaction between pollutants and soil components is strongly influenced by the biophysical-chemical properties of soil components and pollutants [3]. Soil pollution occurs when pollutants pollute the soil surface, enter the soil and settle as toxic chemicals in the soil [4]. Heavy metals can enter the environment anthropologically due to human activities such as through metal plating, mining, smelting, pesticide use, soil fertilizers, etc. [5].

One of dangerous heavy metal is lead $(\mathrm{Pb})$. Lead is one of the ten main chemicals found naturally in the earth's crust and has toxic effects to human health [6]. Soil which is polluted by leador other heavy metal can come from human activities such as waste incineration, burning of coal and petroleum, metal smelting, and others [6]. Direct contamination due to the re-suspension of dust containing lead from soil can be inhaled by

\footnotetext{
*Corresponding author:soesilo@indo.net.id
} 
certain environmental conditions, for example in dry season and the deposition of direct air particulate matter against plant surfaces. Those way are likely to be pathway in which heavy metals in soil and plant accumulation connected [4].

In developing countries, there are around 600.000 new cases resulting intellectual disability of children every year and estimated 143.000 deaths occurs in each year. In Southeast Asia, a half of number diseases due to lead poisoning was occurred and a fifth part happened in Western and Eastern Mediterranean Pacific regions[7][8].Lead poisoning recorded by WHO (2010) occurred in the region of Nigeria causing more than 100 children of Dareta Village and Yargalma poisoning. Severe exposure to lead pollution also occurred in urban areas in Sacramento, California in 2009. The data showed that almost 3\% of children in the region have blood lead levels of more than $4.5 \mathrm{mg} / \mathrm{dL}$ [3].

On average, 10-30\% lead is being inhaled and absorbed through the lungs while about $5-10 \%$ lead is ingested and absorbed through the gastrointestinal tract [9]. Acute lead poisoning symptom are usually characterized by anxiety, poor focus, headache, muscle tremor, abdominal cramps or complaints of abdominal pain, kidney damage, hallucinations and forgetfulness and all these symptoms occur at level of 100-120 $\mu \mathrm{g} / \mathrm{dL}$ lead in blood for adults. Signs of chronic lead poisoning in adults occur when lead level blood around 50$80 \mu \mathrm{g} / \mathrm{dL}$, with symptoms of fatigue, insomnia, headaches, joint pain, gastrointestinal symptoms. In adults who areexposed after one to two years at the workplace, blood lead level reach around 40-60 $\mu \mathrm{g} / \mathrm{dL}$ and will have symptoms such as muscle weakness, lack of intelligence, symptoms of peripheral and gastrointestinal neuropathic damage [10].

\section{Materials and Methods}

The aim of the study was to analyze health impact of lead contamination in people especially people who lived in Pesarean Village. The study involved 51 respondents who lived in Pesarean Village, Adiwerna Subdistrict, Tegal District in area of RT 37 RW 08. The samples was determined by purposive sampling method with criteria people who had taken their blood in 2015 by Environmental Health, Ministry of Health, Yogyakarta Indonesia (BTKL Yogyakarta, Indonesia)[11] and stayed at least 10 years in Pesarean Village. Analysis of health impact was carried out using questionnaire. Questionnaires obtained were matched with secondary data and literature on diseases caused by lead contamination.

\section{Results and Discussions}

Based on the results of health impact conducted by questionnaires supported by Adiwerna district health center data and interview, metal and used lead acid battery (ULAB) smelting activity in the past have a major health impact on surrounded people especially in breathing. Data from Health center of Adiwerna District in 2015 and 2016 showed that diarrhea, skin problem and tuberculosis were the main diseases which often experienced by Pesarean villagers.

The result also showed that $80 \%$ of respondents have complaints of coughing, shortness of breath and fever. This can be caused by lead pollution that occurs through the air media especially dust. These symptoms were also in accordance with the symptoms shown by the people of Cinangka Village who have the same conditions as Pesarean Village as the center of the used battery smelting industry. Based on the report of Indonesia Ministry of Environment in 2011 for Cinangka Village,lead poisoning effects in 
gastrointestinal (abdominal cramps, colic) usually began with constipation, nausea, vomiting. Those symptoms are counted as an acute exposure of lead.

The emerging neurological symptom was encephalopathy such as headaches, confusion, frequent fainting. The main mechanism of neurogical disruption is the ionic mechanism which substitution of lead and calcium ions happened. It will allow lead to pass through the blood -brain barrier and when it is penetrated, lead will accumulate in astroglialcells, disrupting myelin sheath formation[12].Lead concentration also can affect the neural excitation and memory that related to neurotransmitter activity [13].The previous research stated that some chronic symptoms of lead poisoning were abdominal and muscular pain, arthralgia, irritability, depression, sleep disordered, memory damage and peripheral nerve damage while gastrointestinal colic caused by high lead exposure and associated with neuropathic damage[10, 12].

In 2013, based on health center data of Adiwerna district, many people inPesarean Villagewere affected by Acute Respiratory Tract Infection (ISPA), weak muscle and tissue systems and the presence of people who were mentally retarded. Dust particles contained lead can enter the lungs and settle in the lungs resulting shortness of breath. The type of disease that appeared above was in accordance with on the acute symptoms of lead poisoning, a common symptom that arises in health due to lead poisoning. Acute intensive exposure can be seen from lead poisoning with symptoms of abdominal pain, constipation, fatigue, anemia and fever [15].The effect of acute exposure of lead beside neurological symptoms, is digestive system related symptomps such as diarhrhea, constipation, nausea and vomiting $[16,17]$.

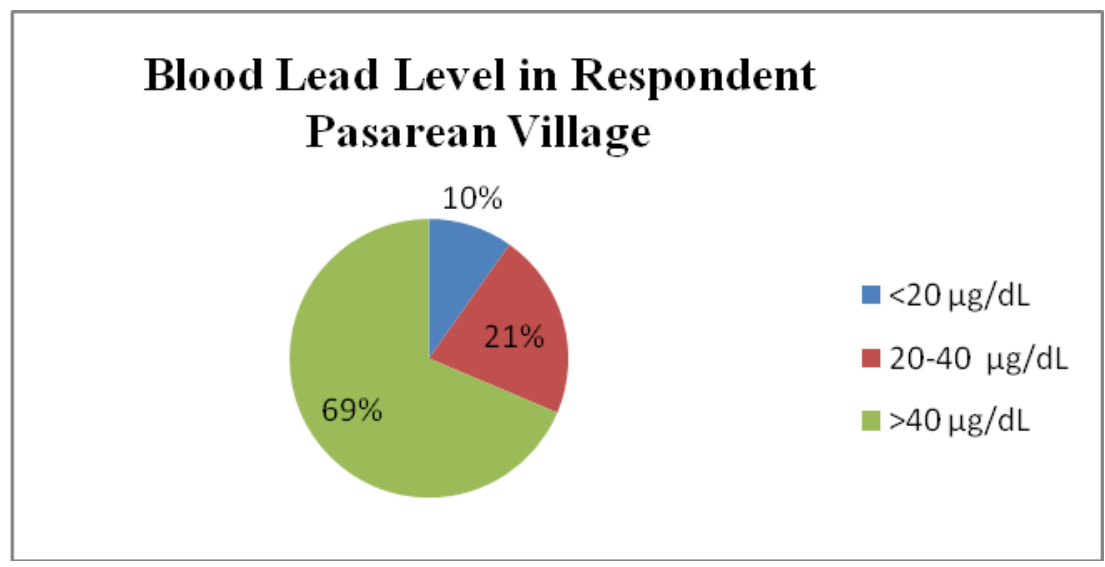

Fig.1. Blood Lead Level in Respondent Pesarean Village

Based on the results of the examination conducted by Environmental Health, Ministry of Health Indonesia (BBTKL Yogyakarta) in 2015 (Figure 1) showed that the majority of respondents had lead levels above $20 \mu \mathrm{g} / \mathrm{dL}$ in blood. While $69 \%$ of respondents had blood lead levels above $40 \mu \mathrm{g} / \mathrm{dL}$. The highest blood lead levels examined were 272.994 $\mu \mathrm{g} / \mathrm{dL}$ which was owned by respondents who worked as smelters.

Health impacts due to lead exposure are felt by all respondents. When linked to the occupation of respondent's profile, $51 \%$ of respondents work as smelters. The results of the questionnaire showed that the complaints most often felt by respondents who worked as smelter were coughing and shortness of breath, aches and abdominal pain. These symptoms can be interpreted as chronic symptoms due to exposure to lead. Lead exposure obtained by 
respondents who work as smelters was counted as occupational exposure through the respiratory and digestive tract which can mostly come from the smelting work environment. It is accordance with previous research that concluded levels of lead in blood can arise in addition of occupational exposure [18].

\section{Conclusion}

Lead pollution due to metal smelting waste and used batteries has an impact on people health. Various acute and chronic symptoms of lead poisoning such as coughing, fatigue, muscle weakness, constipation and constipation were experienced by all respondents and almost $80 \%$ of the results of blood tests showed blood lead levels exceeding the maximum limit set while for the most severe chronic symptoms occurred in one family that had mentally retarded in their children.

\section{Acknowledgments}

This research is funded by The Grant of Indexed International Publication for Final Project of Student/ Publikasi Terindeks Internasional Untuk Tugas Akhir Mahasiswa (PITTA) Universitas Indonesia 2018 with contract number 2587/UN.R31/HKP.05.00/2018.

\section{References}

1. W. Cunningham, M. Cunningham. Environental science : A Global Concern (McGraw Hill Companies, New York, 2012).

2. E.D Enger, B.F Smith. Environmental science: A Study of Interrelationships (McGraw Hill Education, New York, 2016)

3. M.J Solt, M. Daniel, J.K. Mitchelle Inter. J. of Env Res and Pub Health 12 (2015).

4. R. Ferri, D. Hasim, D. Smith, F.Donna, M. Curatolo. J. Science of the Total Env 518 (2015)

5. F.J DeRoss, Smelters and Metal Reclaimenrs (Mosby-Year book, New York, 1997).

6. R.G Mitchell, M. Henry, N.R Lisa, M. Donna, A.S Hannah, G. Lydia, T.L Veronique, S. GretcheN, M. Jonathan. J. Env. Poll. 187 (2014).

7. M.Balali, S.Shademanfar, J.Moghadam, R. Afshari, M. Neghabian . Inter. J. Occup Envi (2010).

8. World Health Organization (WHO). Preventing Disease Through Healthy Environments Exposure To Lead: A Major Public Health Concern (2010)

9. H. Palar. Heavy metal pollution and toxicology (Rineka Cipta, Jakarta, 2004).

10. C.P Nikolas, G. Eleftheria, Hatzidaki, B. Stamatis, N. George, M. T. Aristidis. J. Med Sci Monit 11 (2005).

11. BTKL Yogyakarta, Environmental Health, Minsitry of Health, Indonesia (Yogyakarta, 2015).

12. M.R Cullen, J.M. Robins, B. Eskenazi. J. Medicine (Baltimore), (1983).

13. A. Garza, R. Vega, E. Soto. J. Med SciMonit 12 (2006).

14. J.Bressler, KA. Kim, T. Chakraborti, G. Goldstein. J. Neurochem Res 24 (1999)

15. E. R. Kristina. Disertation. Level of riskof ambient air lead exposure to health problems of elementary school students in south Tangerang (2015).

16. H.C Kim, T.W Jang, H.J Chae, W.J Choi, M.N Ha,B.J Ye, B.G Kim, M.J Jeon, S.Y Kim, Y.S Hong. J. Ann. Of Occup. And Env.Med 27, 30 (2015)

17. JM Pearce. J. Eur Neurol 57 (2007) 
18. A. Mudhipalli. Indian J.Med.Res 126 (2007) 